\title{
Use of out-of-hospital cardiac arrest registries to assess COVID-19 home mortality
}

\author{
Hervé Hubert ${ }^{1,2,3^{*}}$ (D), Valentine Baert ${ }^{1,2}$, Jean-Baptiste Beuscart ${ }^{1}$ and Emmanuel Chazard ${ }^{1}$
}

\begin{abstract}
Background: In most countries, the official statistics for the coronavirus disease 2019 (COVID-19) take account of inhospital deaths but not those that occur at home. The study's objective was to introduce a methodology to assess COVID-19 home deaths by analysing the French national out-of-hospital cardiac arrest (OHCA) registry (RéAC).

Methods: We performed a retrospective multicentre cohort study based on data recorded in the RéAC by 20 mobile medical teams (MMTs) between March 1st and April 15th, 2020. The participating MMTs covered 10.1\% of the French population. OHCA patients were classified as probable or confirmed COVID-19 cases or as non-COVID-19 cases. To achieve our primary objective, we computed the incidence and survival at hospital admission of cases of COVID-19 OHCA occurring at home. Cardiac arrests that occurred in retirement homes or public places were excluded. Hence, we estimated the number of at-home COVID-19-related deaths that were not accounted for in the French national statistics.
\end{abstract}

Results: We included 670 patients with OHCA. The extrapolated annual incidence of OHCA per 100,000 inhabitants was 91.9 overall and 17.6 for COVID-19 OHCA occurring at home. In the latter group, the survival rate after being taken to the hospital after an OHCA was 10.9\%. We estimated that 1322 deaths were not accounted in the French national statistics on April 15, 2020.

Conclusions: The ratio of COVID-19 out-of-hospital deaths to in-hospital deaths was $12.4 \%$, and so the national statistics underestimated the death rate.

Keywords: COVID-19, Out-of-hospital cardiac arrest, COVID-19 home mortality, Epidemiology

\section{Background}

The severity of the coronavirus disease 2019 (COVID19) is directly related to resulting health complications like severe acute respiratory syndrome, septic shock, sepsis, and cardiac, thrombotic or thromboembolic disorders [1-7]. These complications can lead to out-ofhospital cardiac arrest (OHCA) when patients are not

\footnotetext{
* Correspondence: herve.hubert@univ-lille.fr

'University of Lille, CHU Lille, ULR 2694 - METRICS: Évaluation des

Technologies de Santé et des Pratiques Médicales, University of Lille, F-59000 Lille, France

${ }^{2}$ French National Out-of-Hospital Cardiac Arrest Registry, Lille, France

Full list of author information is available at the end of the article
}

rapidly admitted to hospital [8,9]. The World Health Organization (WHO) and most national governments provided daily death COVID-19 counts. The COVID-19 mortality rates are difficult to estimate because the total number of infected patients in a given country will depend on the national or regional testing strategy. Moreoadditional

ver, most COVID-19 death counts are limited to inhospital deaths, which is unlikely to account for all COVID-19 mortalities. At the beginning of April, the French Ministry of Health started to include care home deaths in the official statistics, which led to a marked

C C The Author(s). 2020 Open Access This article is licensed under a Creative Commons Attribution 4.0 International License, which permits use, sharing, adaptation, distribution and reproduction in any medium or format, as long as you give appropriate credit to the original author(s) and the source, provide a link to the Creative Commons licence, and indicate if changes were made. The images or other third party material in this article are included in the article's Creative Commons licence, unless indicated otherwise in a credit line to the material. If material is not included in the article's Creative Commons licence and your intended use is not permitted by statutory regulation or exceeds the permitted use, you will need to obtain permission directly from the copyright holder. To view a copy of this licence, visit http://creativecommons.org/licenses/by/4.0/ The Creative Commons Public Domain Dedication waiver (http://creativecommons.org/publicdomain/zero/1.0/) applies to the data made available in this article, unless otherwise stated in a credit line to the data. 
jump in the total COVID-19-related death count in France. Many deaths at home are still not accounted for or even assessed in official statistics [10]. In many countries, the strategy for hospital-based COVID-19 management involves detecting high-risk patients who require hospitalization and specific care. Patients with few or mild symptoms may not be hospitalized, and are instructed to go to the emergency department only if their condition deteriorates [11]. However, healthcare professionals have noticed that a patient's condition sometimes deteriorates very quickly. It is not known how often COVID-19 patients die as a result of an acute clinical deterioration that starts at home, i.e. before they are admitted to the emergency room or even before a mobile medical team (MMT) arrives. The present study's objective was to introduce a methodology to assess the number of COVID-19 patients who die at home. To this end, we analysed data from the French national out-ofhospital cardiac arrest (OHCA) registry (RéAC) [12].

\section{Methods}

\section{Study setting}

France has a two-tiered system for prehospital emergency medical assistance. The first tier corresponds to a fire department ambulance for rapid intervention and the provision of basic life support (BLS). The second tier corresponds to a mobile emergency and resuscitation service (MERS) comprising one or more MMTs, which can provide advanced life support (ALS) if required [13]. Medical dispatch centers are responsible for out-of-hospital emergency coordination. During OHCA interventions, all MMTs used a specific Utstein-style RéAC form to document patient data, times, care provision, and immediate survival status $[12,14]$. Lastly, the data are stored in the RéAC's secure database (www.registreac.org).

\section{Time period and population}

In this retrospective multicentre cohort study, we collected OHCA data, from 20 MERSs (Argenteuil, Aulnaysous-Bois, Bobigny, Corbeil-Essonnes, Creteil, Douai, Garches, Grenoble, Lyon, Melun, Montfermeil, Nantes, Orléans, Rennes, Roanne, Roubaix, Selestat, Saint-Denis, Tourcoing, and Troyes) in towns and cities throughout France (Fig. 1) during a 46-day study period (from March 1st to April 15th, 2020). Hence, these centres covered an at-risk population of 6,793,921 inhabitants in Paris, its suburbs and in rural and urban towns of all sizes elsewhere in France. The study population was representative of the French population as a whole. We selected these 20 MERSs because we had checked that

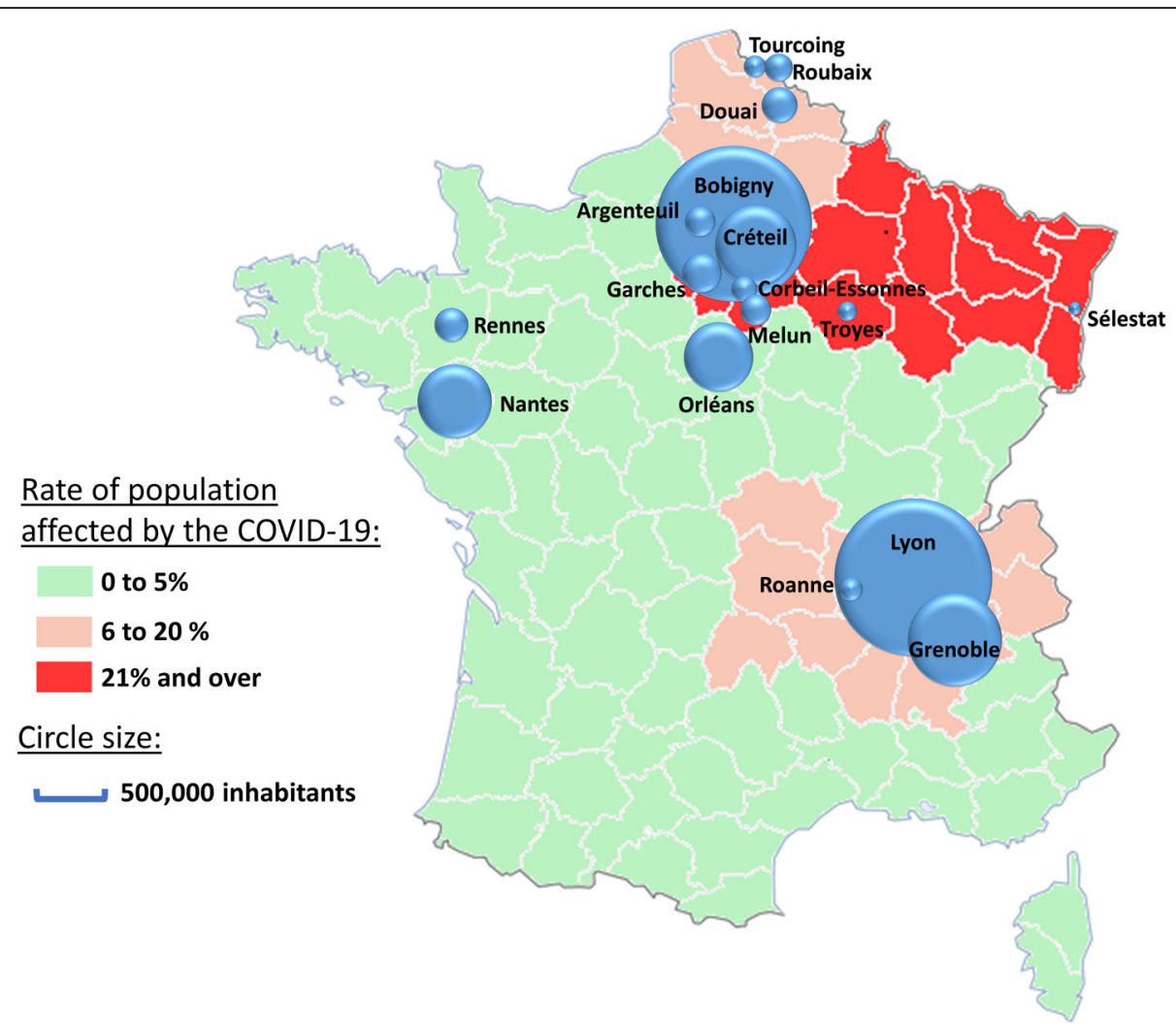

Fig. 1 Participating centers, populations covered, and the rate of COVID-19 contamination on April 15th, 2020, by French administrative region. Bobigny comprises four MERSs (in Aulnay-sous-Bois, Bobigny, Montfermeil, and Saint-Denis). Original figures created by the authors 
they included all their OHCAs in the RéAC; the data were always quality-controlled and the patient's COVID19 stats was always recorded. Trauma-related OHCAs were excluded. All the data (including the patient's COVID status) were collected prospectively. Individuals with OHCA were classified as probable or confirmed COVID-19 cases or as non-COVID-19 cases as defined by the World Health Organization [15].

A probable case was defined as "a suspect case for whom testing could not be performed for any reason or for whom testing for the COVID-19 virus is inconclusive". In this context, patients had:

- consulted a physician because of COVID-19 symptoms.

- met WHO criteria A, B or C (acute respiratory illness AND (A) a history of travel to or residence in a location reporting community transmission of COVID-19 disease during the 14 days prior to symptom onset or (B) having been in contact with a confirmed or probable COVID-19 case in the last 14 days prior to symptom onset or $(\mathrm{C})$ in the absence of an alternative diagnosis that fully explains the clinical presentation) [15].

- not received a laboratory confirmation of COVID-19 but were considered as probable cases. Indeed, little testing was performed in France during the study period, and the tests that were performed were mainly limited to in-hospital and severe cases of COVID-19.

A confirmed case is defined by the WHO as "a person with laboratory confirmation of COVID-19 infection, irrespective of clinical signs and symptoms". Hence, patients with laboratory-confirmed COVID-19 (after inhospital or outpatient screening) and allowed to return home or remain at home (because of low severity) were considered as confirmed cases.

All other patients were included in the non-COVID19 group.

This information was collected prospectively or gathered (after an auscultation) by the MMT's emergency physician. We pooled probable and confirmed COVID19 cases into a COVID-19 OHCA group.

\section{Statistical analysis and incidence assessment}

Quantitative variables were expressed as mean \pm standard deviation (SD). Categorical variables were expressed as number of cases and percentage. COVID-19 group and Non COVID-19 groups were compared. For quantitative variables, we used a Student $t$ test and the result was reported as the mean difference, and its $95 \%$ confidence interval. For qualitative variable, we used a Fisher's exact test, and its result was reported as the odds ratio (computed using the conditional maximum likelihood estimate) and its 95\% confidence interval (CI).

To calculate incidence, we used data published in 2020 by the French National Institute of Statistics and Economic Studies (INSEE). These incidences were adjusted for age (in age classes: $0-29$; 30-49; 50-65; 6575 ; $>75$ years) and sex. We computed the overall annual age- and sex-adjusted incidence of OHCA, the incidence in the non-COVID-19 OHCA group, and the incidence in the COVID-19 OHCA group. Lastly, to achieve our primary objective, we computed the incidence and survival at hospital admission in the "COVID-19 OHCA at home" group. The latter group did not include cases of CA that occurred in retirement homes or in public places, which were already accounted for in the French national statistics.

All statistical analyses were performed with SPSS software (version 25.0; IBM, Armonk, NY, USA). The threshold for statistical significance was set to $p<0.05$.

\section{Results}

We analysed 670 OHCAs. Of these, 146 were categorized into the COVID-19 group (127 probable cases and 19 confirmed cases). The mean age of the overall study population was $68.2 \pm 17.2$, with no difference between the COVID-19 and non-COVID-19 groups (difference and 95\% CI: -0.90 [-4.09;2.23], $p=0.565$ ). The population was predominantly male $(68.8 \%)$, and there was a significant difference between the COVID-19 and nonCOVID-19 groups $(60.3 \%$ vs. $71.2 \%$ males, respectively; odds ratio and $95 \%$ confidence intervals (OR [95\%CI]) 0.61 [0.41;0.92], $p=0.015$ ). Most OHCAs occurred at home (85.2\%), with no significant difference between the groups in this respect (OR [95\%CI] 1.61 [0.92;3.03], $p=$ 0.099). A history of diabetes was more frequent in the COVID-19 group than in the non-COVID-19 group (21.2\% vs. $13.0 \%$, respectively; OR [95\%CI] 1.82 [1.09; 2.94], $p=0.017$ ). The two groups differed with regard to the causes of the OHCAs; relative to the COVID-19 group, the frequency of cardiac causes was higher in the non-COVID-19 group (34.9\% vs. $72.9 \%$, respectively; OR [95\%CI] $0.20[0.13 ; 0.30], p<0.001)$ and the frequency of respiratory causes was lower $(54.1 \%$ vs. $9.9 \%$, respectively; OR [95\%CI] 11.11 [6.67;16.67], $p<0.001)$. There were no differences between the COVID-19 and nonCOVID-19 groups with regard to the frequency of survival at hospital admission (10.3\% vs. $13.9 \%$, respectively; OR [95\%CI] $0.71[0.36 ; 1.30], p=0.271)$. These results correspond to 131 out the 146 deaths in the COVID-19 group and 451 of the 524 deaths in the non-COVID-19 group. The characteristics are detailed in Table 1.

The equivalent overall annual age- and sex-adjusted incidence of OHCA was 91.9 per 100,000 inhabitants. The equivalent annual age- and sex-adjusted incidences 
Table 1 Description and comparison of the COVID-19 OHCA and non-COVID-19 OHCA in France from March 1st to April 15th, 2020

\begin{tabular}{|c|c|c|c|c|}
\hline & $\begin{array}{l}\text { COVID-19 } \\
\text { OHCA } \\
(N=146)\end{array}$ & $\begin{array}{l}\text { Non-COVID-19 } \\
\text { OHCA } \\
(N=524)\end{array}$ & Estimated effect size $^{a}$ & $p$ \\
\hline \multicolumn{5}{|l|}{ Context of the OHCA } \\
\hline Age - yr & $67.5 \pm 17.5$ & $68.4 \pm 17.1$ & $-0.90[-4.09 ; 2.23]$ & 0.565 \\
\hline Sex (male) - no. (\%) & $88(60.3 \%)$ & $373(71.2 \%)$ & $0.61[0.41 ; 0.92]$ & 0.015 \\
\hline OHCA at home - no. (\%) & $129(88.4 \%)$ & $432(82.4 \%)$ & $1.61[0.92 ; 3.03]$ & 0.099 \\
\hline \multicolumn{5}{|l|}{ Medical history - no. (\%) } \\
\hline - diabetes & $31(21.2 \%)$ & $68(13.0 \%)$ & $1.82[1.09 ; 2.94]$ & 0.017 \\
\hline - cardiovascular & $60(41.1 \%)$ & $228(43.5 \%)$ & $0.91[0.61 ; 1.33]$ & 0.637 \\
\hline - respiratory & $23(15.8 \%)$ & 69 (13.2\%) & $1.23[0.70 ; 2.08]$ & 0.417 \\
\hline - other & $45(30.8 \%)$ & $151(28.8 \%)$ & $1.10[0.72 ; 1.67]$ & 0.681 \\
\hline - unremarkable & $9(6.2 \%)$ & $29(5.5 \%)$ & $1.12[0.46 ; 2.50]$ & 0.840 \\
\hline \multicolumn{5}{|l|}{ Cause of the OHCA - no. (\%) } \\
\hline - cardiac cause & $51(34.9 \%)$ & $382(72.9 \%)$ & $0.20[0.13 ; 0.30]$ & $<0.001$ \\
\hline - respiratory cause & $79(54.1 \%)$ & $52(9.9 \%)$ & $11.11[6.67 ; 16.67]$ & $<0.001$ \\
\hline - other cause & $16(11.0 \%)$ & $90(17.2 \%)$ & $0.60[0.31 ; 1.06]$ & 0.073 \\
\hline Bystander presence (at collapse) - no. (\%) & $94(64.8 \%)$ & $279(53.6 \%)$ & $1.59[1.06 ; 2.38]$ & 0.018 \\
\hline - Immediate bystander BLS ${ }^{b}$ - no. (\%) & $48(52.7 \%)$ & $139(49.6 \%)$ & $1.05[0.64 ; 1.72]$ & 0.631 \\
\hline \multicolumn{5}{|l|}{ Resuscitation } \\
\hline Bystander BLS - no. (\%) & $67(45.9 \%)$ & $237(45.2 \%)$ & $1.03[0.70 ; 1.51]$ & 0.925 \\
\hline Bystander AED use - no. (\%) & $5(6.3 \%)$ & $32(11.3 \%)$ & $0.55[0.16 ; 1.45]$ & 0.215 \\
\hline - if AED used, shock - no. (\%) & $1(20.0 \%)$ & $7(24.1 \%)$ & $0.89[0.02 ; 11.11]$ & 0.999 \\
\hline BLS by first aid providers - no. (\%) & $119(81.5 \%)$ & $405(77.4 \%)$ & $1.30[0.80 ; 2.13]$ & 0.309 \\
\hline ALS by the MMT - no. (\%) & $83(56.8 \%)$ & $312(59.5 \%)$ & $0.89[0.61 ; 1.32]$ & 0.569 \\
\hline \multicolumn{5}{|l|}{ First recorded cardiac rhythm ${ }^{c}$ - no. (\%) } \\
\hline - asystole & $122(83.6 \%)$ & $436(83.4 \%)$ & $1.03[0.62 ; 1.75]$ & 0.999 \\
\hline - VF/pulseless VT & $3(2.0 \%)$ & $35(6.7 \%)$ & $0.29[0.06 ; 0.95]$ & 0.041 \\
\hline - PEA & $15(10.3 \%)$ & $36(6.9 \%)$ & $1.56[0.76 ; 3.03]$ & 0.215 \\
\hline - ROSC during BLS & $6(4.1 \%)$ & $16(3.1 \%)$ & $0.94[0.54 ; 1.58]$ & 0.599 \\
\hline \multicolumn{5}{|l|}{ Times } \\
\hline Time between $T_{0}$ and MMT arrival - min & $30.4 \pm 53.5$ & $23.8 \pm 24.6$ & $6.60[-2.56 ; 15.60]$ & 0.158 \\
\hline Time between $T_{0}$ and ROSC or death - min & $50.8 \pm 52.4$ & $42.0 \pm 27.7$ & $8.80[-0.27 ; 17.88]$ & 0.057 \\
\hline \multicolumn{5}{|l|}{ Survival } \\
\hline ROSC - no. (\%) & $23(15.8 \%)$ & $87(16.7 \%)$ & $0.94[0.54 ; 1.59]$ & 0.900 \\
\hline Survival at hospital admission - no. (\%) & $15(10.3 \%)$ & $73(13.9 \%)$ & $0.71[0.36 ; 1.30]$ & 0.271 \\
\hline
\end{tabular}

COVID-19 SARS-CoV-2 coronavirus; OHCA Out-of-hospital cardiac arrest; BLS Basic life support; AED Automated external defibrillator; MMT Mobile medical team; ALS Advanced life support; VF Ventricular fibrillation; VT Ventricular tachycardia; PEA Pulseless electrical activity; ROSC Return of spontaneous circulation ${ }^{a}$ Odds ratio and $95 \% \mathrm{Cl}$ (Confidence Interval) for categorical variables, mean difference and $95 \% \mathrm{Cl}$ for quantitative variable

$b_{\text {if }}$ the OHCA was witnessed by a bystander

con arrival of the MMT

in the non-COVID-19 OHCA group and the COVID-19 OHCA were respectively 72.0 and 19.9 per 100,000 inhabitants. In the group of COVID-19 OHCAs occurring at home $(n=129)$, the equivalent annual incidence was 17.6 per 100,000 inhabitants; for France as a whole, this would correspond to 1483 OHCAs during the 46-day study period. The survival rate at hospital admission in the COVID-19 OHCA group was $10.9 \%$.

\section{Discussion}

During the first 6 weeks of the COVID-19 epidemic in France, we detected an increase in the overall incidence 
of OHCA of 30.4/100,000 inhabitants. We observed about $50 \%$ more OHCAs than had previously reported for France by Luc et al. [16] (61.5 per 100,000 inhabitants per year). This increase is in line with Marijon et al.'s results [17] in their regional study (Paris and its suburbs).

Of these 30.4 cases of OHCA per 100,000 inhabitants, 17.6 could be attributed to COVID-19 - corresponding to two thirds of the increase in incidence. When OHCA was related to COVID-19, the most frequently cause was a respiratory syndrome (in $50 \%$ of cases), followed by a cardiac cause. This increase in respiratory aetiologies might be directly linked to the rapid development of complications such as severe acute respiratory syndrome or cardiac and thromboembolic distress [2, 18]. Using the survival rate $(10.9 \%)$ and the calculated number of cases of COVID-19 OHCA occurring at home (1483), we estimated that 1322 people in France died at home from COVID-19 over the study period. This number corresponds to one eighth of France's official COVID-19 death count (which covered only in hospital deaths) for the same period $(n=10,643)$.

The increase in OHCA was also related to nonCOVID-19 patients. The RéAC data do not indicate the reason for this increase. Nevertheless, an assumption could be that the prevention of healthcare and/or the chronic disease patients follow up might have been delayed during this pandemic. Indeed, healthcare resources was in majority dedicated to the COVID-19 management [19] and patients with chronic diseases might have dropped out or postponed their follow up [20]. We also hypothesize that some of the increase in the incidence of OHCA is also related to the pandemic situation (novel infections, low levels of testing, lockdown, no changes in the care procedure, more people waiting at home until a fatal deterioration occurred, etc.). These results are consistent with the INSEE study showing an increase $26 \%$ of deaths in France between early March and mid-April 2020 [21].

In the overall population (i.e. COVID-19 and nonCOVID-19 OHCA patients), the survival at hospital admission rate in our study was very low (13.1\%), relative to the value of $21 \%$ observed outside a pandemic period [22]. The same trend was observed for the ROSC rate: $16.5 \%$ in our study vs. $24.0 \%$ in the literature [22]. These lower survival rates might not have been related to COVID-19 because there were no significant differences between the COVID-19 and non-COVID-19 groups. The main factors associated with survival in OHCA (such as patient age or intervention time) were much the same as those previously reported before the pandemic [12, 22, 23]. Only a history of diabetes (a poor prognostic factor for COVID-19) was slightly more prevalent $[24,25]$. When we looked for significant differences between COVID-19 and non-COVID-19 populations, the results highlighted some of the COVID19 patients' characteristics. Indeed, outside of a pandemic period, one usually observes more men, less bystander presence at the time of collapse, more cardiac causes, less respiratory causes, and a greater frequency of shockable rhythms. With regard to these variables, OHCA victims look more like COVID-19 patients than "usual" OHCA victims. The lower survival rates in the COVID-19 group might also be related (at least in part) to how the OHCAs were managed. Our results suggest that the proportion of OHCA patient receiving BLS or ALS from the professional first responders (the fire department or the MMT) was lower than usual. On the whole population, the fire brigade provided BLS in $78.3 \%$ of OHCAs, and the MMT provided ALS in 59.0\% of OHCA. These rates are usually around 85 and $70 \%$, respectively [22, 23]. At the start of the COVID-19 pandemic, there was a lack of clear guidelines on resuscitation. The WHO lists $\mathrm{CPR}$ as an aerosol-generating technique [26], whereas Couper et al.'s [27] recent systematic review could not establish whether or not chest compressions or defibrillation were associated with aerosol generation. In the West Midlands region of the UK, health care teams have been given instructions for the non-resuscitation of patients with suspected or confirmed COVID-19 [28]. This type of guideline was not in force in France. However, French professional first responders (i.e. fire department teams and MMTs) may have been more selective about deciding to resuscitate in this context.

The present study also had some limitations. We did not included data from all French regions. However, included centres came from several different areas (rural or urban) and there was a well balanced between strongly and less impacted by the COVID-19 regions. We classified the aetiologies of OHCA according to Ustein style. However, it is known that differentiating between cardiac and non-cardiac causes is difficult in a pre-hospital setting (as highlighted by Carter and Cone [29]). The very limited access to COVID-19 tests in France during the study period might have prompted us to under- or over-diagnose cases of COVID-19. During this period, auscultation was the most reliable way to determine the patient' COVID-19 status in a prehospital setting. However, in the event of a second epidemic wave, with the current greatest availability of COVID-19 tests, we can now consider the generalization of prehospital RT-PCR tests in order to better identify COVID-19 cases.

\section{Conclusions}

In summary, at-home COVID-19-related deaths corresponded to one eighth of in-hospital deaths, which 
means that 1322 deaths were not accounted for by the French national statistics as of April 15th, 2020. This finding should prompt us to consider improving the triage of COVID-19 patients, in order to improve care strategies, monitor the disease more accurately, and limit home mortality due to the virus. Many countries (e.g. Germany, England, Italia, USA, Canada, Spain, Japan, Australia, Singapore, etc.) have developed their own national OHCA registry. These countries could therefore replicate our methodology and assess their at-home COVID-19 mortality rate.

\section{Abbreviations}

OHCA: Out-of-hospital cardiac arrest; WHO: World health Organization; MERS: Mobile emergency and resuscitation service; MMT: Mobile medical team; RéAC: French national out-of-hospital cardiac arrest registry; INSEE: French national institute of statistics and economic studies; BLS: Basic life support; ALS: Advanced life support

\section{Acknowledgments}

Authors acknowledge Drs: François Javaudin (Nantes) Delphine Hugenschmitt (Lyon), Nadia Mansouri (Creteil), François Revaux (Creteil), Cécile Ursat (Garches), Jean-Marc Agostinucci (Bobigny), Steven Lagadec (Corbeil-Essonnes), Adèle Barbery (Douai), Sylvain Thiriez (Roubaix), Thomas Bony (Troyes), Antoine Leroy (Rennes), Hubert Courcoux (Orléans), Sophie Narcisse (Tourcoing), Fanny Larcher (Sélestat), Olivier Watrelot (Melun), Diego Abarrategui (Argenteuil), Rudy Cohen (Roanne), Coralie Chassin, M.D., Karim Tazarourte (Lyon), Guillaume Debaty (Grenoble), Carlos El khoury (Villeurbanne), Tahar Chouihed (Nancy), Frédéric Adnet (Bobigny), Pierre-Yves Gueugniaud (Lyon), Benoit Jardel (Rouen), Tom Handwerk (Marseille), Celine Le beuan (Valenciennes), Patrice Serre (Bourg-en-Bresse), Romain Bardelay (Corbeil Essonnes), Benoit Genuyt (Lorient), Lucie Ginoux (Gonesse), Carole Guery (Nantes), Alain Guillon (Saint Brieuc), Deborah Jaeger (Nancy), Yoann Jeanmasson (Fort-De-France), Sebastien Jonquet (Besancon), Sarah Lorge (Lyon), David Grua (Roanne), Marion Maurel (Roanne), Sylvie Massacrier (Feurs), Mariane Ovtcharenko (Fontainebleau), Terence Ahui (Béthune), Richard Loubert (Béthune), Yohan Altervain (Corbeil Essonnes), Clément Babin (Agen), Cécile Bonhomme (Le Puy en Velay), Arthur Bourg (Corbeil Essonnes), Alice Conio (Reims), Caroline Duchier (Marseille), Céline Fuseau (Corbeil Essonnes), Nancy Gaillard (Toulon), Frederic Guillaumee (Lyon), Laurent Halbout (Caen), Sébastien Mur (Tarbes), Margaux Muteaud (Corbeil Essonnes), Camille Nussbaum (Corbeil Essonnes), Jessica Picot (Saint-Lô), Géraldine Sauvaget (Saint-Lô), Bruno Simonnet (Bordeaux), Odile Theurey (Lyon), Eric Thibaud (Colmar), Claire-Marie Weyer (Marne-la-Vallée), Karen Barukh (Marne-laVallée), Carine Vanderstraeten (Valenciennes).

We thank David Fraser Ph.D. (Biotech Communication SARL, Ploudalmézeau, France) for copy-editing assistance.

\section{Authors' contributions}

$H H, V B, J B B$, and EC did statistical analyses. $H H, V B, J B B$ and EC drafted the manuscript and figures. $\mathrm{HH}$ and $\mathrm{VB}$ collected and cleaned data. $\mathrm{HH}$ conceived the study and supervised data collection. All authors have read and approved the manuscript.

\section{Funding}

No funding was received for the study.

The RéAC registry is funded by the French Society of Emergency Medicine (SFMU), the Fédération Française de Cardiologie patient association, the Mutuelle Générale de I'Education Nationale (MGEN), the University of Lille, and the Lille Institute of Health Engineering.

The authors declare that the RéAC registry's funding sources had no role in the design, conduct, analysis, interpretation or reporting of the present study.

\section{Availability of data and materials}

Anonymized cardiac arrest data can be requested from scientific committee of the French Cardiac Arrest Registry (RéAC - www.registreac.org). Demographic data are available online in the public domain from the
French National Institute of Statistics and Economic Studies (INSEE - https:// www.insee.fr/fr/statistiques?theme $=0$ ).

\section{Ethics approval and consent to participate}

The registry and subsequent analyses were approved by the French Advisory Committee on Information Processing in Health Research (CCTIRS) and the French National Data Protection Commission (CNIL, reference number 910946). In line with the French legislation on registry analyses, patient consent was not required.

\section{Consent for publication}

Not applicable.

\section{Competing interests}

The authors declare that there are no competing and conflicts of interest.

\section{Author details}

${ }^{1}$ University of Lille, CHU Lille, ULR 2694 - METRICS: Évaluation des Technologies de Santé et des Pratiques Médicales, University of Lille, F-59000 Lille, France. ${ }^{2}$ French National Out-of-Hospital Cardiac Arrest Registry, Lille, France. ${ }^{3}$ Institute of Health Engineering of Lille, ULR 2694 - METRICS, University of Lille, 42 Rue Ambroise Paré, 59120 Loos, France.

Received: 25 September 2020 Accepted: 7 December 2020

Published online: 14 December 2020

\section{References}

1. He H, Hu C, Xiong N, Liu C, Huang X. How to transform a general hospital into an "infectious disease hospital" during the epidemic of COVID-19. Crit Care. 2020;24(1):145.

2. Siordia JA Jr. Epidemiology and clinical features of COVID-19: a review of current literature. J Clin Virol. 2020;127:104357.

3. Chang D, Lin M, Wei L, Xie L, Zhu G, Dela Cruz CS, Sharma L. Epidemiologic and clinical characteristics of novel coronavirus infections involving 13 patients outside Wuhan, China. JAMA. 2020;323(11):1092-3.

4. Huang C, Wang Y, Li X, Ren L, Zhao J, Hu Y, Zhang L, Fan G, Xu J, Gu X, et al. Clinical features of patients infected with 2019 novel coronavirus in Wuhan, China. Lancet. 2020;395(10223):497-506.

5. Wang D, Hu B, Hu C, Zhu F, Liu X, Zhang J, Wang B, Xiang H, Cheng Z, Xiong Y, et al. Clinical characteristics of 138 hospitalized patients with 2019 novel coronavirus-infected pneumonia in Wuhan, China. JAMA. 2020; 323(11):1061-9.

6. Bikdeli B, Madhavan MV, Jimenez D, Chuich T, Dreyfus I, Driggin E, Nigoghossian C, Ageno W, Madjid M, Guo Y, et al. COVID-19 and thrombotic or thromboembolic disease: implications for prevention, antithrombotic therapy, and follow-up: JACC state-of-the-art review. J Am Coll Cardiol. 2020;75(23):2950-73.

7. Fried JA, Ramasubbu K, Bhatt R, Topkara VK, Clerkin KJ, Horn E, Rabbani L, Brodie D, Jain SS, Kirtane AJ, et al. The variety of cardiovascular presentations of COVID-19. Circulation. 2020;141(23):1930-6.

8. Phua J, Weng L, Ling L, Egi M, Lim CM, Divatia JV, Shrestha BR, Arabi YM, Ng J, Gomersall CD, et al. Intensive care management of coronavirus disease 2019 (COVID-19): challenges and recommendations. Lancet Respir Med. 2020:8(5):506-17.

9. Zheng Z, Peng F, Xu B, Zhao J, Liu H, Peng J, Li Q, Jiang C, Zhou Y, Liu S, et al. Risk factors of critical \& mortal COVID-19 cases: a systematic literature review and meta-analysis. J Inf Secur. 2020;81(2):e16-25.

10. Baldi E, Sechi GM, Mare C, Canevari F, Brancaglione A, Primi R, Klersy C, Palo A, Contri E, Ronchi V, et al. COVID-19 kills at home: the close relationship between the epidemic and the increase of out-of-hospital cardiac arrests. Eur Heart J. 2020;41(32):3045-54.

11. Sun Q, Qiu H, Huang M, Yang Y. Lower mortality of COVID-19 by early recognition and intervention: experience from Jiangsu Province. Ann Intensive Care. 2020;10(1):33.

12. Hubert H, Tazarourte K, Wiel E, Zitouni D, Vilhelm C, Escutnaire J, Cassan P, Gueugniaud PY, ReAC GR. Rationale, methodology, implementation, and first results of the French out-of-hospital cardiac arrest registry. Prehosp Emerg Care. 2014;18(4):511-9.

13. Adnet $F$, Lapostolle F. International EMS systems: France. Resuscitation. 2004; 63(1):7-9. 
14. Perkins GD, Jacobs IG, Nadkarni VM, Berg RA, Bhanji F, Biarent D, Bossaert LL, Brett SJ, Chamberlain D, de Caen AR, et al. Cardiac arrest and cardiopulmonary resuscitation outcome reports: update of the utstein resuscitation registry templates for out-of-hospital cardiac arrest: a statement for healthcare professionals from a task force of the international liaison committee on resuscitation (American heart association, European resuscitation council, Australian and New Zealand council on resuscitation, heart and stroke foundation of Canada, InterAmerican heart foundation, resuscitation council of Southern Africa, resuscitation council of Asia); and the American heart association emergency cardiovascular care committee and the council on cardiopulmonary, critical care, perioperative and resuscitation. Circulation. 2015;132(13):1286-300.

15. WHO: Global surveillance for COVID-19 caused by human infection with COVID-19 virus. 202020 March. (https://doi.org/https://apps.who.int/iris/rest/ bitstreams/1272502/retrieve).

16. Luc G, Baert V, Escutnaire J, Genin M, Vilhelm C, Di Pompeo C, Khoury CE, Segal N, Wiel E, Adnet F, et al. Epidemiology of out-of-hospital cardiac arrest: a French national incidence and mid-term survival rate study. Anaesth Crit Care Pain Med. 2019;38(2):131-5.

17. Marijon E, Karam N, Jost D, Perrot D, Frattini B, Derkenne C, Sharifzadehgan A, Waldmann V, Beganton F, Narayanan K, et al. Out-of-hospital cardiac arrest during the COVID-19 pandemic in Paris, France: a population-based, observational study. Lancet Public Health. 2020;5(8):e437-43.

18. Ruan Q, Yang K, Wang W, Jiang L, Song J. Clinical predictors of mortality due to COVID-19 based on an analysis of data of 150 patients from Wuhan, China. Intensive Care Med. 2020:46(5):846-8.

19. Moghadas SM, Shoukat A, Fitzpatrick MC, Wells CR, Sah P, Pandey A, Sachs JD, Wang Z, Meyers LA, Singer BH, et al. Projecting hospital utilization during the COVID-19 outbreaks in the United States. Proc Natl Acad Sci U S A. 2020;117(16):9122-6.

20. Heckman GA, Saari M, McArthur C, Wellens NIH, Hirdes JP. COVID-19 outbreak measures may indirectly lead to greater burden on hospitals. CMAJ. 2020;192(14):E384

21. Gascard N, Kauffmann B, Labosse A. 26\% de décès supplémentaires entre début mars et mi-avril 2020 : les communes denses sont les plus touchées In: INSEE, editor. Insee Focus. 191 2020. (https://doi.org/https://www.insee.fr/ $\mathrm{fr} /$ statistiques/4488433).

22. Castra L, Genin M, Escutnaire J, Baert V, Agostinucci JM, Revaux F, Ursat C, Tazarourte K, Adnet F, Hubert H. Socioeconomic status and incidence of cardiac arrest: a spatial approach to social and territorial disparities. Eur $J$ Emerg Med. 2019;26(3):180-7.

23. Baert V, Vilhelm C, Escutnaire J, Marc JB, Wiel E, Tazarourte K, Goldstein P, Khoury $C E$, Hubert $H$, Genin $M$, et al. Identification of a morning out-ofhospital cardiac arrest cluster of high-incidence: towards a chronopreventive care strategy. J Eval Clin Pract. 2020.

24. Guo W, Li M, Dong Y, Zhou H, Zhang Z, Tian C, Qin R, Wang H, Shen Y, Du $\mathrm{K}$, et al. Diabetes is a risk factor for the progression and prognosis of COVID19. Diabetes Metab Res Rev. 2020:e3319. https://doi.org/10.1002/dmrr.3319. Epub ahead of print. PMID: 32233013; PMCID: PMC7228407.

25. Wu C, Chen X, Cai Y, Xia J, Zhou X, Xu S, Huang H, Zhang L, Zhou X, Du C et al. Risk factors associated with acute respiratory distress syndrome and death in patients with coronavirus disease 2019 pneumonia in Wuhan, China. JAMA Intern Med. 2020;180(7):934-43.

26. WHO: Modes of transmission of virus causing COVID-19: implications for IPC precaution recommendations. 2020. (https://doi.org/https://www.who. int/news-room/commentaries/detail/modes-of-transmission-of-viruscausing-covid-19-implications-for-ipc-precaution-recommendations).

27. Couper K, Taylor-Phillips S, Grove A, Freeman K, Osokogu O, Court R, Mehrabian A, Morley PT, Nolan JP, Soar J, et al. COVID-19 in cardiac arrest and infection risk to rescuers: a systematic review. Resuscitation. 2020;151: 59-66.

28. Mahase E, Kmietowicz Z. Covid-19: doctors are told not to perform CPR on patients in cardiac arrest. BMJ. 2020;368:m1282.

29. Carter RM, Cone DC. When is a cardiac arrest non-cardiac? Prehosp Disaster Med. 2017;32(5):523-7.

\section{Publisher's Note}

Springer Nature remains neutral with regard to jurisdictional claims in published maps and institutional affiliations.

\section{Ready to submit your research? Choose BMC and benefit from}

- fast, convenient online submission

- thorough peer review by experienced researchers in your field

- rapid publication on acceptance

- support for research data, including large and complex data types

- gold Open Access which fosters wider collaboration and increased citations

- maximum visibility for your research: over $100 \mathrm{M}$ website views per year

At BMC, research is always in progress.

Learn more biomedcentral.com/submissions 